\title{
Antagonists of embryo-derived platelet-activating factor prevent implantation of mouse embryos*
}

\author{
N. R. Spinks and C. O'Neill \\ Human Reproduction Unit, Royal North Shore Hospital of Sydney, St Leonards, \\ New South Wales 2056, Australia
}

\begin{abstract}
Summary. Inhibitors of platelet activation, alprazolam, iloprost and SRI 63-441, were used to demonstrate the necessity of embryo-derived platelet-activating factor (PAF) activity for the establishment of pregnancy in mice. In a splenectomized mouse bioassay $6 \mu \mathrm{g}$ alprazolam inhibited, for $3 \mathrm{~h}$, the thrombocytopenia induced by $0.1 \mu \mathrm{g} \mathrm{PAF}$; $4 \mu \mathrm{g}$ iloprost and $0 \cdot 5 \mu \mathrm{g}$ SRI $63-441$ were effective for 6 and $12 \mathrm{~h}$ respectively. The administration of $2 \mu \mathrm{g}$ iloprost $/ 30 \mathrm{~g}$ body weight on Days 1 and 4 of pregnancy and twice daily on Days 2 and 3 caused a $50 \%$ reduction $(P<0.0005)$ in the number of implantation sites in the uterus at Day 8 of pregnancy, without affecting $(P>0.05)$ the number of corpora lutea. A similar reduction in the number of implantation sites was achieved with $20 \mu \mathrm{g}$ SRI $63-441 / 30 \mathrm{~g}$ body weight/day. The reduction in implantation rate was evident on Day 5 of pregnancy by visualizing the implantation sites with pontamine sky blue. SRI 63-441 had no effect on peripheral blood progesterone concentrations from Day 1 to Day 9 of pregnancy, and did not appear to inhibit implantation by blocking the preimplantation surge of oestradiol. The number and morphology of blastocysts flushed from the uterus of Day 4 inhibitor-treated mice was not different $(P>0.05)$ from the controls. The cleavage rate and morphology of embryos cultured from the 2-cell to blastocyst stage in media containing SRI 63-441 or iloprost $(10 \mu \mathrm{g} / \mathrm{ml})$ were normal, precluding a gross toxic effect. Simultaneous administration of $1 \mu \mathrm{g}$ PAF-acether to treated animals re-established pregnancy rates to levels not significantly different $(P>0.05)$ from the controls.
\end{abstract}

Keywords: mouse; implantation; PAF; iloprost; alprazolam; SRI 63-441

\section{Introduction}

Mouse and human preimplantation embryos produce a platelet-activating factor (PAF) which is homologous to 1-o-alkyl-2-acetyl-sn-glyceryl-3-phosphocholine (PAF-acether) (O'Neill, 1985b, c; Collier et al., 1988). This embryo-derived PAF is responsible for the contraction of the spleen and mild thrombocytopenia seen throughout early pregnancy in mice (O'Neill, 1985a). The production of embryo-derived PAF by human embryos has been correlated with the pregnancy potential of embryos produced by in-vitro fertilization (O'Neill \& Saunders, 1984; O'Neill et al., 1987), suggesting that its production is necessary for the establishment of pregnancy. A preliminary study (Spinks \& O'Neill, 1987) demonstrated that PAF inhibitors given before implantation in mice blocked the establishment of pregnancy. The present paper extends these observations and investigates the possible mechanisms of action of PAF on the establishment of pregnancy.

\section{Materials and Methods}

Stock solutions of $20 \mu \mathrm{g}$ iloprost/ml (ZK 36374; Schering AG, Berlin, F.R.G.), and $500 \mu \mathrm{g} \mathrm{SRI} \mathrm{63-441/ml} \mathrm{(Sandoz}$ Research Institute, East Hanover, NJ, U.S.A.) were prepared in Dulbecco's phosphate-buffered saline (PBS) (8.2 g

*Reprint requests to Dr C. O'Neill. 
$\mathrm{NaCl}, 0.2 \mathrm{~g} \mathrm{KCl}, 1.15 \mathrm{~g} \mathrm{Na}_{2} \mathrm{HPO}_{4}$ and $0.2 \mathrm{~g} \mathrm{KH}_{2} \mathrm{PO}_{4}$, per litre). A stock solution of alprazolam (Upjohn Pty. Ltd, Kalamazoo, MI, U.S.A.) was dissolved in ethanol at a concentration of $3 \mu \mathrm{g} / \mathrm{ml}$, and stored at $-20^{\circ} \mathrm{C}$. Working dilutions were prepared in PBS. Stock solutions of PAF-acether (Sigma Chemical Co., St Louis, MO, U.S.A.) were obtained in chloroform $(1 \mu \mathrm{g} / \mathrm{ml})$ and stored in reacti-vials (Pierce Chemical Co., Rockford, IL, U.S.A.) at $-20^{\circ} \mathrm{C}$. Working dilutions were prepared by evaporating the chloroform, under $\mathrm{N}_{2}$, and diluting to the required concentration with PBS containing $0.25 \%$ bovine serum albumin (Commonwealth Serum Laboratories, Melbourne, Victoria, Australia).

\section{Potency of antagonists}

The ability of SRI 63-441 and iloprost to inhibit PAF-acether-induced thrombocytopenia was tested in an in-vivo bioassay (O’Neill, 1985b, 1987; O’Neill et al., 1987). Random-bred Swiss albino mice of the Quackenbush strain (Department of Veterinary Physiology, University of Sydney, NSW, Australia) were splenectomized and allowed to recover for 7 days and then given intraperitoneal (i.p.) injections of various doses of inhibitors followed immediately by $0 \cdot 1 \mu \mathrm{g}$ PAF-acether. Blood $(10 \mu \mathrm{l})$ was taken from the peri-orbital plexus, under light ether anaesthesia, using $10 \mu 1$ microcaps (Drummond Scientific Co., Broomall, PA, U.S.A.). The blood was diluted in $1 \mathrm{ml}$ ammonium oxalate (1\% w/v). Platelet counts were performed immediately before and $30 \mathrm{~min}$ after the injection of PAF-acether, using a Neubauer haemocytometer.

To determine the length of time these inhibitors were active in vivo, animals were given i.p. injections of PAFacether at $0,3,6,12$ or $24 \mathrm{~h}$ after the injection of the inhibitor. Platelet counts were performed as described above.

\section{$P A F$ antagonists in early pregnancy}

Ovulation was synchronized in 8-week-old mice with 3 i.u. PMSG (i.p.) (Folligon: Intervet, Boxmeer, The Netherlands) followed, $48 \mathrm{~h}$ later, by $3 \mathrm{i} . \mathrm{u}$. hCG (Chorulon: Intervet). The mice were paired with males of proven fertility, and the presence of a vaginal plug the next morning indicated Day 1 of pregnancy. Iloprost was administered at concentrations of 0, 0.5, 1 and $2 \mu \mathrm{g} / 30 \mathrm{~g}$ body weight in $200 \mu \mathrm{l} \mathrm{PBS,} \mathrm{i.p.,} \mathrm{at} \mathrm{16:00} \mathrm{h} \mathrm{on} \mathrm{Day} \mathrm{1,} \mathrm{09:00} \mathrm{and} \mathrm{16:00} \mathrm{h} \mathrm{on}$ Days 2 and 3, and 09:00 $\mathrm{h}$ on Day 4. SRI 63-441 was administered at concentrations of $0,4,10,20$, and $40 \mu \mathrm{g} / 30 \mathrm{~g}$ body weight in $200 \mu$ PBS, i.p., at 16:00 h on Day 1 and 09:00 h on Days 2-4. Necropsies were performed on Day 8 of pregnancy and the number of implantation sites, and corpora lutea were determined. Any evidence of embryonic resorption was noted.

To ensure that the effects of the inhibitors were PAF specific, some inhibitor-treated animals were simultaneously treated with PAF-acether, administered (i.p.) at doses of $0,0.5$ and $1 \mu \mathrm{g} / 30 \mathrm{~g}$ body weight for iloprost-treated animals and at doses of 1 and $2 \mu \mathrm{g} / 30 \mathrm{~g}$ body weight for SRI 63.441-treated animals. PAF-acether injections were given at 16:00 $\mathrm{h}$ on Day 1 of pregnancy, 09:00 and 16:00 h on Days 2 and 3, and at 09:00 $\mathrm{h}$ on Day 4.

\section{Effect of antagonists on uterine vascular permeability}

To test whether PAF antagonists inhibit the increased vascular permeability at the site of implantation on Day 4 of pregnancy, the implantation sites were visualized using Pontamine Sky Blue 6BX (BDH Chemicals Ltd, Poole,

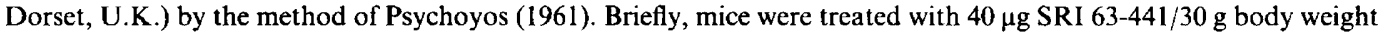
$(200 \mu \mathrm{l})$ or PBS at $16: 00 \mathrm{~h}$ on Day 1 of pregnancy and 09:00 h on Days 2-4. At 15 min before the animals were killed (Day 5) they received an i.v. injection of $0.15 \mathrm{ml}$ of $1 \%$ solution of Pontamine Sky Blue 6BX in PBS. The number of blue areas in the uterine horns was recorded.

\section{Effects of antagonists on oestradiol and progesterone concentrations}

Mice were treated with $40 \mu \mathrm{g}$ SRI $63-441 / 30 \mathrm{~g}$ body weight $(200 \mu \mathrm{l})$ or PBS at 16:00 h on Day 1 of pregnancy and 09:00 h on Days 2-4. To determine peripheral blood progesterone concentrations blood samples were collected, from the periorbital plexuses, at 11:00 h on Days 1-9, using heparinized Pasteur pipettes.

Plasma progesterone was measured by radioimmunoassay with the Amerlex-M Progesterone RIA Kit (Amersham International plc, Amersham, U.K.) with reference standards ranging from 1 to $127 \mathrm{nmol} / \mathrm{l}$. The sensitivity of the assay was typically $0.08 \mathrm{ng} / \mathrm{ml}(0.25 \mathrm{nmol} / 1)$. The cross-reactivity with steroids was $12 \cdot 06 \%$ for $5 \alpha$-pregnan-3,20dione, $6.57 \%$ for $5 \beta$-pregnan-3,20-dione, $1.38 \%$ for corticosterone and $<0.86 \%$ for other progestagens, androgens and oestrogens.

To test that SRI 63-441 was not inhibiting implantation by blocking the preimplantation surge in oestradiol, pregnant animals were treated with $40 \mu \mathrm{g}$ SRI $63-441$ as previously described. On Days 4-8 animals received s.c. injections of $0.1 \mathrm{ml}$ peanut oil or $0.1 \mathrm{ml}$ peanut oil containing $25 \mathrm{ng}$ oestradiol.

\section{Effects of antagonists on embryos}

To determine the effects of inhibitors on the preimplantation embryos in vivo, both iloprost ( $2 \mu \mathrm{g} / 30 \mathrm{~g}$ body weight) and SRI $63-441(20 \mu \mathrm{g} / 30 \mathrm{~g}$ body weight) were administered to 8-week-old pregnant mice as described previously. 
These animals were autopsied on Day 4, the uteri were flushed with Hepes-buffered medium (Quinn et al., 1985) and the morphology and development stage of the embryos were determined.

To examine the effects of these inhibitors on embryos in vitro, 2-cell embryos were flushed from the oviducts of 6 week-old superovulated mice (10 i.u. PMSG and 10 i.u. hCG) with Hepes-buffered medium, rinsed twice and cultured for $72 \mathrm{~h}$ in $50 \mu \mathrm{l}$ droplets of medium (Quinn et al., 1985) under oil in Falcon tissue-culture dishes (Becton-Dickinson Co., Rutherford, NJ, U.S.A.). Culture media contained 0,5 or $10 \mu \mathrm{g}$ iloprost $/ \mathrm{ml}$ or $0,5,10$ or $20 \mu \mathrm{g} \mathrm{SRI} 63-441 / \mathrm{ml}$.

\section{Statistical analysis}

Data for determining the potency of the inhibitors were analysed by the Kruskal-Wallis test, while the effect of the inhibitors on implantation rates were evaluated by analysis of variance and, when appropriate, by Student's $t$ test. The effects of the antagonists on the embryos were analysed by Pearson's $\chi^{2}$ test. Differences in blood progesterone concentrations between control and inhibitor-treated animals were evaluated by two-way analysis of variance.

\section{Results}

\section{Potency of inhibitors}

Splenectomized mice displayed a significant $(P<0.001)$ decrease in platelet count when challenged with $0 \cdot 1 \mu \mathrm{g}$ PAF-acether (Fig. 1). This thrombocytopenia was inhibited by SRI 63-441 $\left(E D_{50}=0.26 \mu \mathrm{g}\right)$. SRI 63-441 was 10 and 15 times more effective than iloprost $\left(E_{50}=3.0 \mu \mathrm{g}\right)$ and alprazolam $\left(\mathrm{ED}_{50}=4.0 \mu \mathrm{g}\right)$ respectively (Fig. 1).

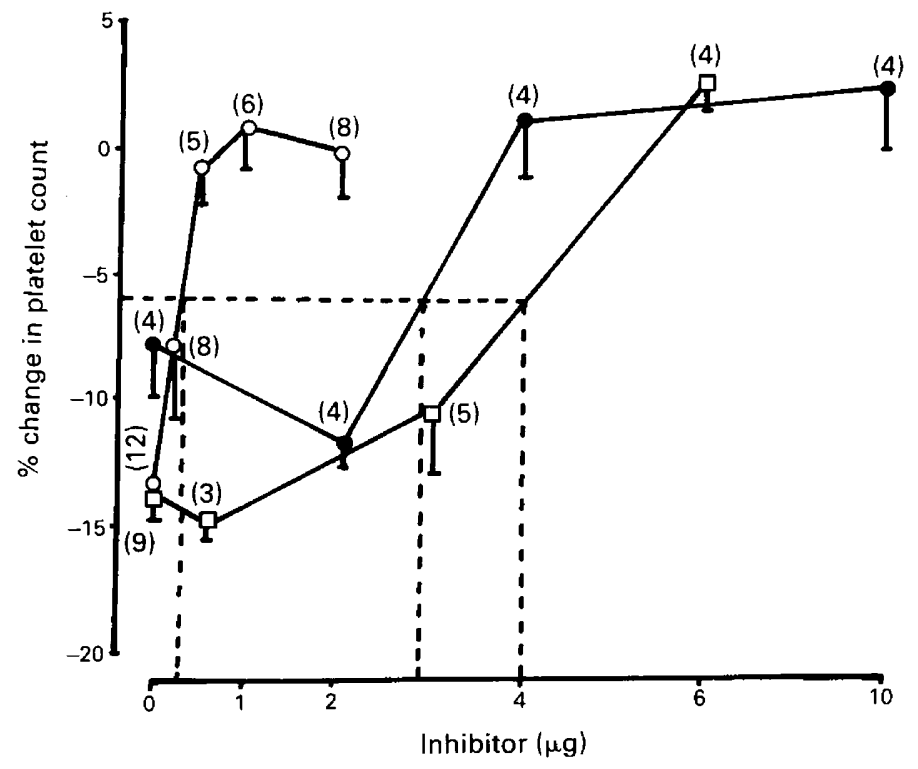

Fig. 1. Changes in the peripheral platelet count of splenectomized mice induced by $0 \cdot 1 \mu \mathrm{g}$ PAFacether and its inhibition by alprazolam $(\square-\square)$, iloprost $(-\bullet)$ and SRI 63-441 (O- $\bigcirc)$. Each point represents the mean \pm s.e.m. for the number of animals in parentheses.

SRI 63-441 $(0.5 \mu \mathrm{g})$ effectively $(P<0.05)$ inhibited the mild thrombocytopenia induced by $0.1 \mu \mathrm{g}$ PAF-acether for up to $24 \mathrm{~h}$ (Fig. 2), while $4.0 \mu \mathrm{g}$ iloprost was effective $(P<0.05)$ for $6 \mathrm{~h}$ and $6.0 \mu \mathrm{g}$ alprazolam $(P<0.05)$ for only $3 \mathrm{~h}$. Consequently, SRI $63-441$, administered daily, and iloprost, administered twice daily, were used in experiments to determine the effects of embryo-derived PAF in early pregnancy. 


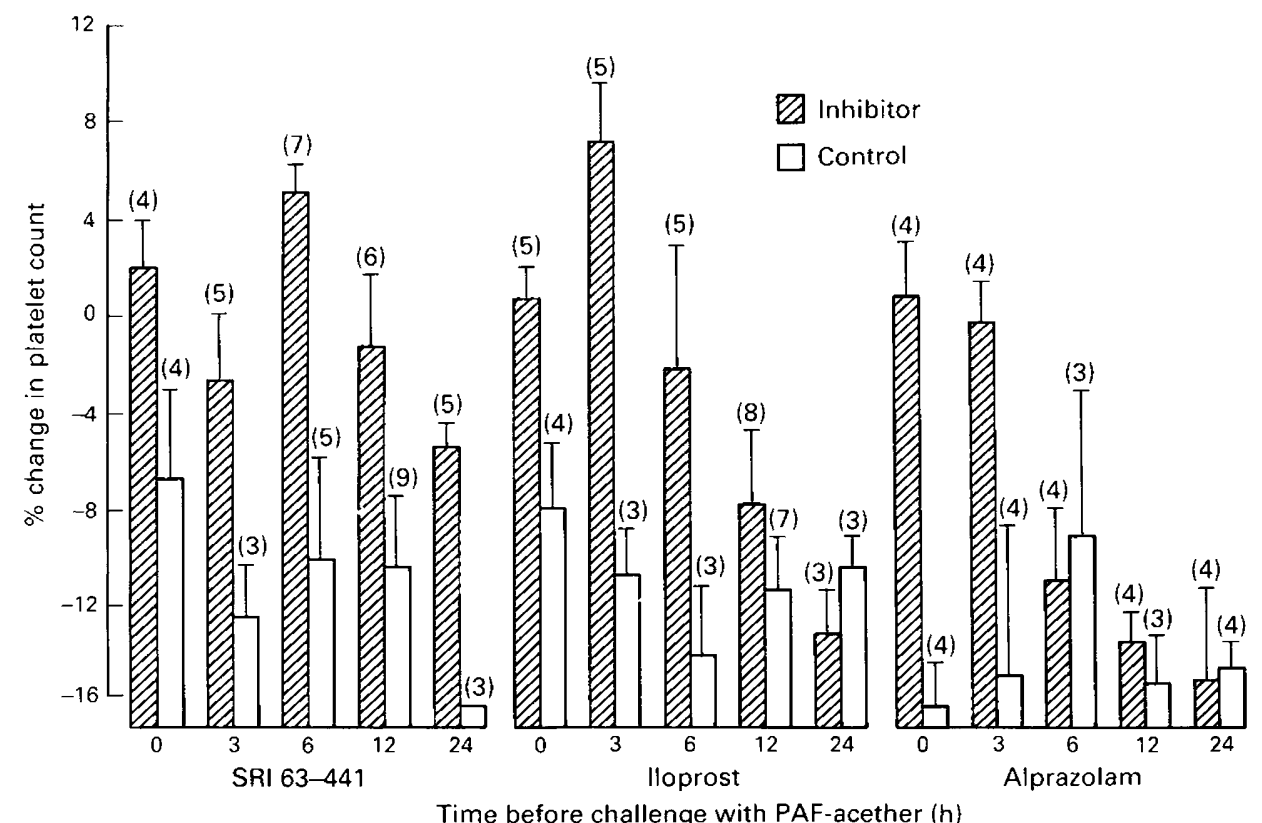

Fig. 2. The percentage change in peripheral blood platelet counts of splenectomized mice challenged with $0.1 \mu \mathrm{g}$ PAF-acether at $0,3,6,12$ or $24 \mathrm{~h}$ after the administration of antagonist. Each point represents mean \pm s.e.m. for the number of animals in parentheses.

\section{$P A F$ antagonists in early pregnancy}

Doses of 1 and $2 \mu \mathrm{g}$ iloprost $/ 30 \mathrm{~g}$ body weight administered over the preimplantation period significantly reduced the number of implantaticn sites compared with control levels (Fig. 3a). Similar results were obtained when SRI 63-441 was administered at doses of 10,20 and $40 \mu \mathrm{g} / 30 \mathrm{~g}$ body weight (Fig. 3b). There was no significant effect $(P>0.05)$ of treatment on the number of corpora lutea per ovary $(18 \cdot 82 \pm 0 \cdot 68)$.

Simultaneous administration of $0.5 \mu \mathrm{g}$ PAF-acether, with $2 \mu \mathrm{g}$ iloprost and $1 \mu \mathrm{g}$ PAF-acether with $20 \mu \mathrm{g}$ SRI 63-441 was sufficient to restore the number of implantation sites to levels not significantly different from the controls (Fig. 4).

\section{Effects of antagonists on uterine vascular permeability}

SRI 63-44I $(40 \mu \mathrm{g})$ inhibited the local increase in vascular permeability surrounding the implantation site, visualized by a blue band of dye in the uterus. The control group $(6 \cdot 70 \pm 1 \cdot 48, \mathrm{~N}=5)$ had significantly $(P<0.012, t$ test $)$ more blue bands than did the inhibitor-treated group $(1.67 \pm 0.64, \mathrm{~N}=6)$.

\section{Effects of antagonists on oestradiol and progesterone concentrations}

The number of implantation sites in the group receiving $40 \mu \mathrm{g}$ SRI 63-441 throughout the preimplantation period was significantly different from the control group (Table 1). The administration of $25 \mathrm{ng}$ oestradiol from Days 4 to 8 of pregnancy had no effect on the implantation rate of the inhibitor-treated or the control groups.

Control and SRI 63-441-treated pregnant animals showed no significant difference $(P>0 \cdot 05)$ in peripheral blood progesterone concentrations throughout the first 9 days of pregnancy (Fig. 5). 

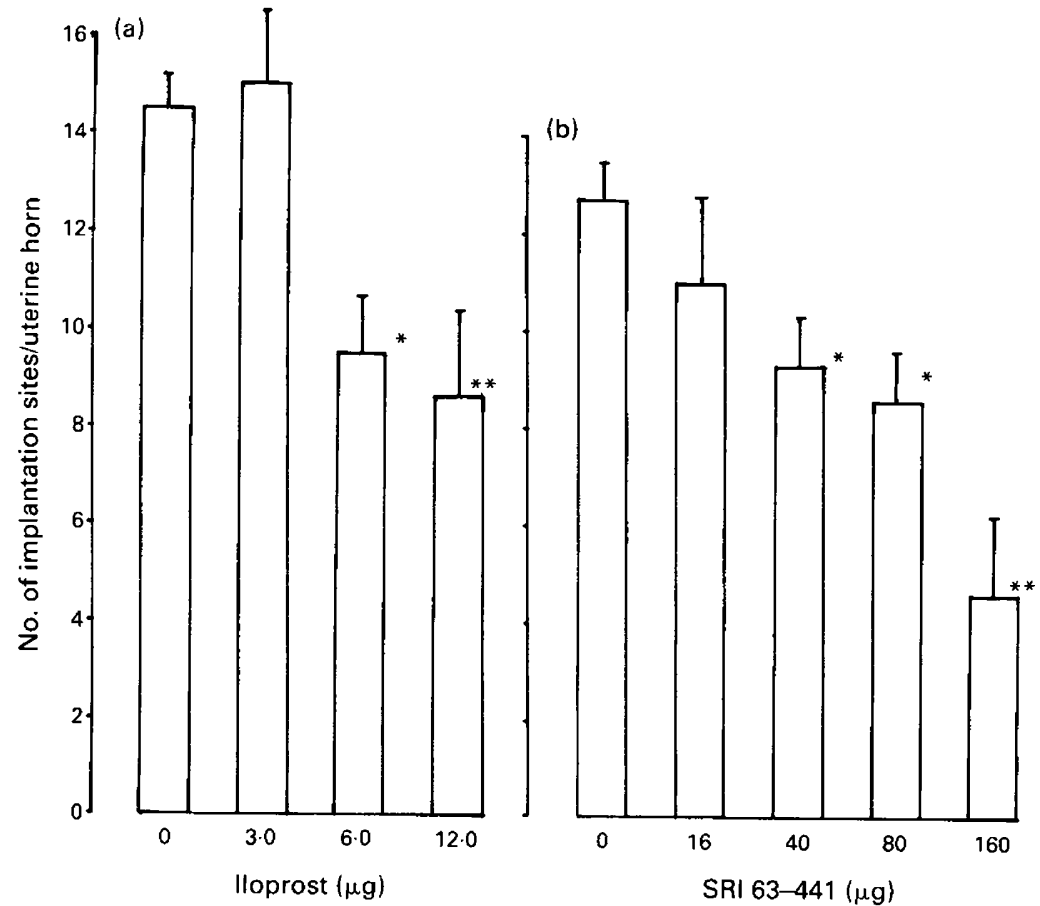

Fig. 3. The effects of iloprost (a) and SRI 63-441 (b) on the number of implantation sites per uterine horn in the mouse. Each column represents the mean \pm s.e.m. for the number of animals in parentheses. ${ }^{*} P<0.0005,{ }^{* *} P<0.0001$ compared with control.

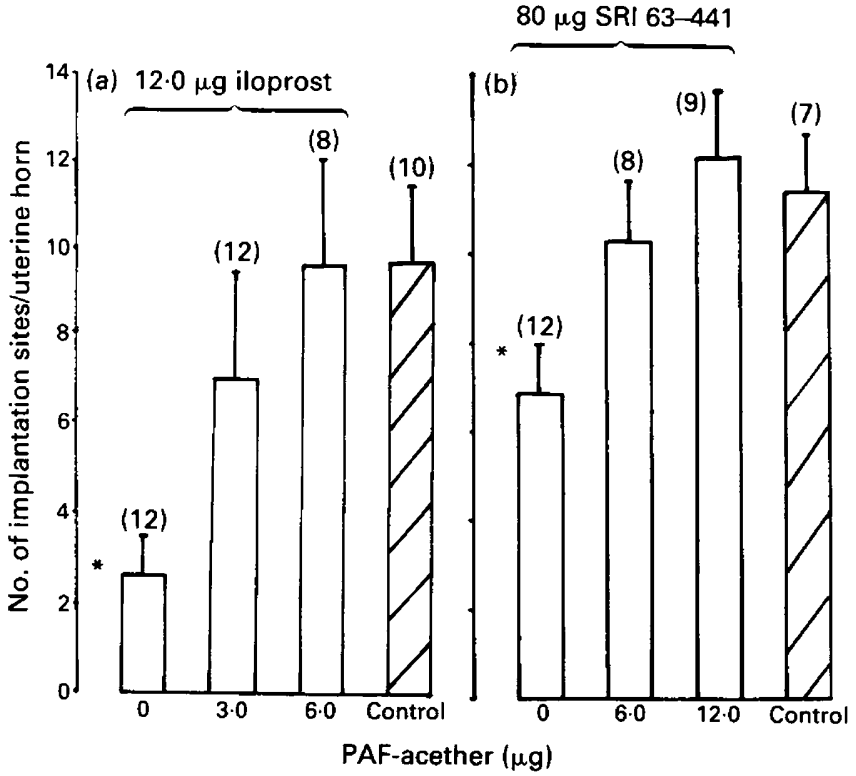

Fig. 4. The effects of PAF on the implantation rate in mice treated with iloprost (a) and SRI 63441 (b). Each column represents the mean \pm s.e.m. for the number of animals in parentheses. ${ }^{*} P<0.0001$ compared with controls. 
Table 1. The effects of SRI $63-441(40 \mu \mathrm{g} / 30 \mathrm{~g}$ body weight on Days 1-4) and oestradiol ( $25 \mathrm{ng}$ on Days 4-8) on the number of implantation sites per uterine horn in mice

\begin{tabular}{lcccc}
\hline & \multicolumn{3}{c}{ Treatment } \\
& $\begin{array}{c}\text { PBS }+ \\
\text { oil }\end{array}$ & $\begin{array}{c}\text { PBS }+ \\
\text { oestradiol }\end{array}$ & $\begin{array}{c}\text { SRI 63-44I } \\
+ \text { oil }\end{array}$ & $\begin{array}{c}\text { SRI 63-441 } \\
\text { +oestradiol }\end{array}$ \\
\hline $\begin{array}{l}\text { No. of animals } \\
\text { No. of implantation sites/ } \\
\text { uterine horn }\end{array}$ & 5 & 5 & 5 & 5 \\
\hline
\end{tabular}

Values are mean \pm s.e.m.

Values with different superscripts differ significantly by two-way analysis of variance $(P<0 \cdot 025)$.

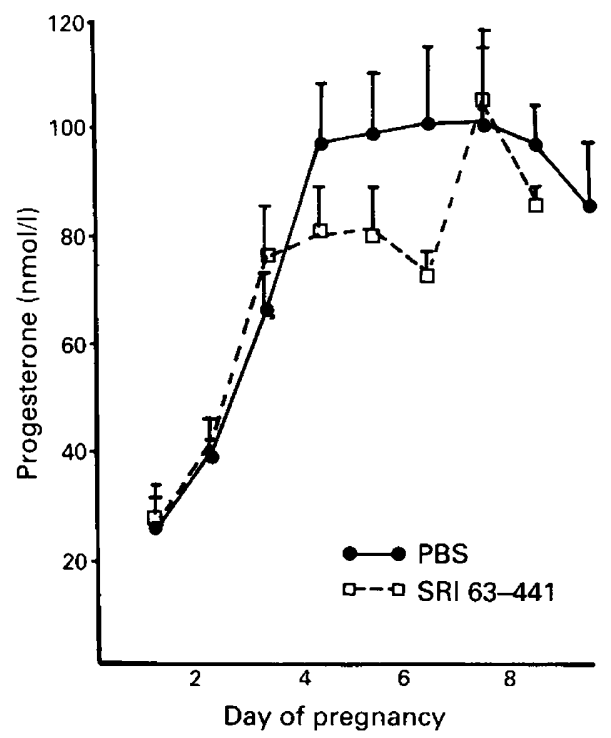

Fig. 5. The effects of SRI 63-441 on the peripheral blood progesterone concentrations throughout the first 9 days of pregnancy in mice.

\section{Effects of antagonists on embryos}

The rate of development and proportion of embryos which degenerated were unaffected $(P>0.05)$ by the exposure of the female to doses of iloprost or SRI 63-441 that inhibited implantation. In all treatment groups more than $80 \%$ of the embryos were at the morula or blastocyst stage by Day 4 of pregnancy, while fewer than $20 \%$ had undergone degeneration. The presence of $10 \mu \mathrm{g}$ iloprost $/ \mathrm{ml}$ or $10 \mu \mathrm{g}$ SRI $63-441 / \mathrm{ml}$ in the culture media did not affect $(P>0.05)$ the development of 2-cell embryos to the blastocyst stage over $72 \mathrm{~h}$ of culture.

\section{Discussion}

PAF is known to increase vascular permeability (Bonnet et al., 1981), cause vasodilatation leading to a transient hypotension (Blank et al., 1979) and bronchoconstriction (Denjean et al., 1981). At 
the cellular level PAF induces activation of platelets (Snyder, 1985) and leucocytes (O'Flaherty et al., 1981) as well as aortic smooth muscle and renal epithelial cells (Kawaguchi \& Yasuda, 1986) through its stimulation of phospholipase $\mathrm{C}$ leading to the breakdown of phosphatidylinositol, the formation of phosphatidic acid (Berridge et al., 1984) and inositol triphosphate, resulting in the phosphorylation of proteins and mobilization of $\mathrm{Ca}^{2+}$. It is this mobilization of $\mathrm{Ca}^{2+}$ that leads to activation of these target cells.

Iloprost, a stable analogue of prostacyclin, reduces peripheral and pulmonary vascular resistance and increases cardiac output (Ylitalo et al., 1984) and urinary excretion (Ylitalo et al., 1985). At the cellular level iloprost stimulates adenyl cyclase activity leading to increased cAMP levels and a reduction in cytoplasmic calcium (Kaser-Glanzmann et al., 1977). Reduced calcium levels inhibit phospholipase C (Broekmann et al., 1980). Reduced calcium levels also inhibit phospholipase $\mathrm{A}_{2}$, blocking the formation of arachidonic acid, and cyclo-oxygenase, blocking the formation of prostaglandins which promote platelet activation (Vanderhoek \& Feinstein, 1979). SRI 63-441 is a specific PAF-acether receptor antagonist (Handley et al., 1986) while alprazolam is a specific inhibitor of PAF-induced platelet activation (Sethy \& Harris, 1982) by an as yet undefined mechanism. The aim of this study was to use these inhibitors to determine whether embryo-derived PAF activity, measured by platelet activation, is essential for the establishment of pregnancy in the mouse.

Iloprost, SRI 63-441 and alprazolam all significantly inhibited the ability of PAF-acether to induce thrombocytopenia in mice (Fig. 1). The kinetics of this inhibition were the same for PAF-acether as for embryo-derived PAF (Ammit et al., 1986), confirming that these two are homologous. lloprost caused an increase in the peripheral platelet count $3 \mathrm{~h}$ after administration (Fig. 2). This increase in platelet count may be due to the increased haematocrit caused by the vasodilatation and increased vascular permeability attributed to prostacyclin (Murata et al., 1979). Alprazolam was effective only for a short period in vivo (Fig. 2) and so was not studied further.

Both SRI 63-441 and iloprost significantly reduced the number of implantation sites in the uterus (Fig. 3). This was not due to gross toxic effects on the embryos since normal development of 2-cell embryos through to the blastocyst stage occurred in the presence of these inhibitors at concentrations that significantly inhibited implantation (Table 1), although embryos cultured in media containing the highest concentrations of inhibitor $(20 \mu \mathrm{g} \mathrm{SRI} 63-441 / \mathrm{ml}$ or $10 \mu \mathrm{g}$ iloprost $/ \mathrm{ml})$ produced fewer blastocysts after $72 \mathrm{~h}$ of culture $(P>0.05)$. Moreover, blastocysts flushed from the uterus of inhibitor-treated females on Day 4 of pregnancy had normal morphology and development rates. Although animals treated with SRI 63-441 and iloprost produced fewer blastocysts by Day 4 of pregnancy, and more morulae than control animals $(P>0.05)$, suggesting some small influence over embryonic development during the preimplantation period, this does not explain the inhibition of implantation observed.

The earliest physiological sign of implantation is a local increase in vascular permeability surrounding the site of implantation. This can be visualized as a band of blue dye in the uterus 15 min after the administration (i.v.) of $1 \%$ Pontamine Sky Blue (Psychoyos, 1961). PAF inhibitortreated animals had significantly $(P<0.012)$ fewer blue bands in the uterus on Day 4 of pregnancy, indicating that these antagonists inhibited the initiation of implantation and were not blocking implantation at later stages.

The mean numbers of corpora lutea were similar for all treatment groups. Iloprost has no effects on peripheral progesterone concentrations in rats (W. Elger, personnal communication) and SRI 63-441 had no effect on progesterone values in pregnant mice (Fig. 5). SRI 63-441 is therefore not acting as a luteolysin.

A surge in oestradiol concentrations on Day 4 of pregnancy is required for embryo implantation to take place in the rat and mouse (Mayer, 1959). Administration of exogenous oestradiol failed to overcome the inhibition of implantation in inhibitor-treated animals (Table 1) and therefore these inhibitors did not appear to exert their effects by blocking the preimplantation surge in oestradiol. 
In the rodent pituitary, prolactin is the major luteotrophic hormone of early pregnancy (McNatty et al., 1976). Braquet \& Rola-Pleszczynski (1987) have suggested that PAF induces the release of prolactin from the rat anterior pituitary, hence PAF antagonists may block implantation by blocking the release of pituitary prolactin. However, progesterone concentrations in inhibitortreated animals are similar to the controls (Fig. 5), demonstrating adequate luteal function in these animals. Furthermore, prostacyclin has been reported (Wright \& Hedge, 1981; Ottlecz et al., 1984) to stimulate prolactin release from rat anterior pituitary tissue, and so iloprost, a prostacyclin analogue, is unlikely to be an antiluteotrophin.

Embryo-derived PAF activity was essential for the establishment of pregnancy in the mouse, since iloprost and SRI 63-441 inhibited implantation in a dose-dependent manner, and this inhibition was overcome by the simultaneous administration of PAF-acether (Fig. 4). The mechanism by which embryo-derived PAF exerted its effects on implantation was not explained by this study. Gasic \& Gasic (1970) suggested a role for platelets in implantation after demonstrating a reduction in the number of implantations in mice treated with anti-platelet antiserum. Platelets are known to secrete, upon activation, growth factors such as platelet-derived growth factor (PDGF) (Witte et al., 1978; Kaplan et al., 1979) which regulate specific target cells in culture by inducing DNA synthesis and cell division (Deul et al., 1985). Blastocyst activation and associated trophoblast outgrowth in vitro require serum supplements. O'Neill et al. (1986) demonstrated that this outgrowth was readily supported by platelet-rich serum while being poorly supported by plateletdepleted serum, suggesting that platelet-derived trophic factors, released upon platelet activation by PAF, may have a role in supporting implantation.

The poor correlation between the effectiveness of the PAF inhibitors to inhibit the thrombocytopenia caused by PAF-acether, and their effectiveness as inhibitors of implantation, suggests that the mechanism by which embryo-derived PAF influences implantation may not be solely mediated by platelet activation. SRI 63-441 and iloprost inhibited the PAF-induced thrombocytopenia in splenectomized mice with relative potencies of 0.8 and $11.2 \mathrm{nmol} / 30 \mathrm{~g}$ body weight, respectively, but iloprost had a higher relative potency $(5.6 \mathrm{nmol} / 30 \mathrm{~g}$ body weight/day) for inhibiting implantation compared to SRI $63-441(30.2 \mathrm{nmol} / 30 \mathrm{~g}$ body weight/day).

Other possible actions of embryo-derived PAF include the mediation of inflammation, peripheral vascular dilatation and vascular permeability (Demopoulos et al., 1979; Benveniste, 1981). It does not seem, however, that the major action of PAF in implantation is via its vasoactive actions since, in the guinea-pig iloprost potentiates PAF-induced vasopermeability (Archer et al., 1984). PAF has now been demonstrated (Orozco et al., 1986) to cause the changes to lymphocyte physiology, as defined by the rosette inhibition test, previously attributed to early pregnancy factor (Morton et al., 1976). Furthermore, O'Neill (1987) also showed an enhanced progesterone production by human granulosa cells in vitro in the presence of PAF, although a luteotrophic role for PAF in vivo has yet to be demonstrated.

Apart from these effects of PAF on maternal physiology, embryo-derived PAF is able to enhance directly the metabolism of pre-implantation embryos in vitro as demonstrated by the enhanced utilization of lactate (Ryan et al., 1987), suggesting an autacoid function for embryoderived PAF. An essential role for embryo-derived PAF in early pregnancy is established by this study. Whether its role is to supply platelet-derived trophic factors to the embryo by activating maternal blood platelets, to act as a preimplantation luteotrophin, to affect uterine receptivity, to affect embryonic development directly, or a combination of all of these is yet to be determined.

We thank Dr E. Schillinger AG, Berlin, F.R.G. (iloprost), Dr D. Handley, Sandoz Research Institute, East Hanover, NJ, U.S.A. (SRI 63-441) and Dr R. B. Ruskin, Upjohn, Kalamazoo, MI, U.S.A. (alprazolam) for their generous gifts; and Mr M. Jones and Ms A. J. Ammit for advice on statistical analysis. This work was supported by an NH and MRC grant No. 860550. N.R.S. is supported by a RNSH post-graduate scholarship. 


\section{References}

Ammit, A.J., Collier, M., Saunders, D.M., O'Neill, C. (1986) Development of a quantitative bioassay for embryo-derived platelet-activating factor. Proc. Aust. Soc. Reprod. Biol. 18, 2, Abstr.

Archer, C.B., Frohlich, C.P., Page, W., Paul, J., Morley, J. \& MacDonald, D.M. (1984) Synergistic interaction between prostaglandins and PAF-acether in experimental animals and man. Prostaglandins 27,495-501.

Benveniste, J. (1981) Platelet activating factor: Present status. Agents Actions 11, 542-544.

Berridge, M.J., Heslop, J.P., Irvine, R.F. \& Brown, K.D. (1984) Inositol triphosphate formation and calcium mobilization in Swiss 3T3 cells in response to plateletderived growth factors. Biochem. J. 222, 195-201.

Blank, M.L., Snyder, F., Byers, W.L., Brooks, B. \& Muirhead, E.E. (1979) Antihypertensive activity of an alkyl ether analog of phosphatidylcholine. Biochem. Biophys. Res. Commun. 90, 523-534.

Bonnet, J., Loiseau, A.M., Orvoen, M. \& Bessin, P. (1981) Platelet-activating factor (PAF-acether) involvement in acute inflammatory and pain processes. Agents Actions 11, 8-10.

Braquet, P. \& Rola-Pleszczynski, M. (1987) Platelet activating factor and cellular immune responses. Immunology Today 8, 345-352.

Broekmann, M.J., Ward, J.W. \& Marcus, A.J. (1980) Phospholipid metabolism in stimulated human platelets. Changes in phosphatidylinositol, phosphatidic acid and lysophospholipids. J. Clin. Invest. 66, 275-283.

Collier M., O'Neill, C., Ammit, A.J. \& Saunders, D.M. (1988) Biochemical and pharmacological characterisation of human embryo-derived platelet activating factor. Human Reprod. (in press).

Demopoulos, C.A., Pinckard, R.N. \& Hanahan, D.J. (1979) Platelet-activating factor: evidence for 1-0alkyl-2-acetyl-sn-glycerol-3-phosphocholine as the active component (a new class of lipid chemical mediators). J. Biol. Chem. 254, 9355-9358.

Denjean, A., Arnoux, B., Benveniste, J., Lockhart, A. \& Masse, R. (1981) Bronchoconstriction induced by intratracheal injection of platelet-activating factor (PAF-acether) in baboons. Agents Actions 11, 12-15.

Deul, T.F., Tong, B.D. \& Huang, J.S. (1985) Plateletderived growth factors: Structure, function and roles in normal and transformed cells. Curr. Top. Cell. Regul. 26, 51-65.

Gasic, G.J. \& Gasic, T.B. (1970) Total suppression of pregnancy in mice by postcoital administration of neuraminidase. Proc. natn. Acad. Sci. U.S.A. 67, 793-798.

Handley, D.A., Tomesch, J.C. \& Saunders, R.N. (1986) Inhibition of PAF-induced systemic responses in the Rat, Guinea-pig, Dog and Primate by the receptor antagonist SRI 63-441. Thromb. Haemost. 56, 40-44.

Kaplan, K.L., Broekmann, M.J., Chernoff, A., Lesznik, G.R. \& Drillings, M. (1979) Platelet alpha-granule proteins: Studies on release and subcellular localization. Blood 53, 604-618.

Kaser-Glanzmann, R., Jakabova, M., George, J.M. \& Luscher, E.F. (1977) Stimulation of calcium uptake in platelet membrane vesicles by adenosine 3', 5'-cyclic monophosphate and protein kinase. Biochim. Biophys. Acta. 466, 429-440.

Kawaguchi, H. \& Yasuda, H. (1986) Platelet-activating factor stimulates prostaglandin synthesis in cultured cells. Hypertension 8, 192-197.

Mayer, G. (1959) Recent studies on the hormonal control of delayed implantation and super-implantation in the rat. Mem. Soc. Endocr. 6, 76-86.

McNatty, K.P., Neal, P. \& Baker, T.G. (1976) Effect of prolactin on the production of progesterone by mouse ovaries in vitro. J. Reprod. Fert. 47, 155-156.

Morton, H., Hegh, V.\& Clunie, G.J.A. (1976) Studies of the rosette inhibition test in pregnant mice: evidence of immunosuppression. Proc. R. Soc. B. 193, 413-419.

Murata, S., Chang, W.C., Tsurufuji, S. \& Morita, I. (1979) The possible roles of prostacyclin $\left(\mathrm{PGI}_{2}\right)$ and Thromboxanes in chronic inflammation. In Advances in Inflammation Research, pp. 436-465. Eds G. Weissman, B. Samuelsson \& R. Paoletti. Raven Press, New York.

O'Flaherty, J.T., Wykle, R.L. \& Miller, C.H. (1981) 1-0alkyl-sn-glyceryl-3-phosphocholine, a novel class of neutrophil stimulants. Am. J Pathol 103, 70-78.

O'Neill, C. (1985a) Thrombocytopenia is an initial maternal response to fertilization in mice. $J$. Reprod. Fert. 73, 559-566.

O'Neill, C. (1985b) Examination of the cause of early pregnancy thrombocytopenia in mice. $J$. Reprod. Fert. 73, 567-577.

O'Neill, C. (1985c) Partial characterization of the embryo-derived platelet activating factor in mice. $J$. Reprod. Fert. 75, 375-380.

O'Neill, C. (1987) Embryo-derived platelet activating factor: a preimplantation embryo mediator of maternal recognition of pregnancy. Dom. Animal Endocr. 4, 69-86.

O'Neill, C. \& Saunders, D.M. (1984) Assessment of embryo quality. Lancet. 2, 1034-1035.

O'Neill, C., Amos, E., Mote, P. \& Gidley-Baird, A. (1986) Histological and ultrastructural evidence for platelet activation in the reproductive tract during early pregnancy Proc. Aust. Soc. Reprod. Biol. 18, 11, Abstr.

O'Neill, C., Gidley-Baird, A.A., Pike, I.I. \& Saunders, D.M. (1987) A bio-assay for embryo-derived platelet activating factor as a means of assessing quality and pregnancy potential of human embryos. Fert. Steril. 47, 969-975.

Orozco, C., Perkins, F. \& Clarke, F.M. (1986) Platelet activating factor induces the expression of early pregnancy factor activity in female mice. J. Reprod. Fert. 78, 549-555.

Ottlecz, A., Samson, W.K. \& McCann, S.M. (1984) A possible role of prostacyclin to stimulate prolactin and growth hormone release by hypothalamic and pituitary actions, respectively. Endocrinology 114, 359-363.

Psychoyos, A. (1961) Permeabilite capillaire et decidualization uterine. C. r. hebd. Séanc. Acad. Sci., Paris, D 252, 1515-1517.

Quinn, P., Warnes, G.M., Kerin, J.F. \& Kirby, C. (1985) Culture factors affecting the success rate of in-vitro 
fertilization and embryo transfer. Ann. N.Y. Acad. Sci. 195-203.

Ryan, J.P., Wiegand, M.H., O'Neill, C. \& Wales, R.G. (1987) In-vitro development and metabolism of lactate by mouse embryos in the presence of platelet activating factor (PAF). Proc. Aust. Soc. Reprod. Biol. 19, 47, Abstr.

Sethy, V.H. \& Harris, D.W. (1982) Determination of biological activity of alprazolam, triazolam and their metabolites. J. Pharm. Pharmacol. 34, 115-116.

Snyder, F. (1985) Chemical and biochemical aspects of platelet activating factor: A novel class of acetylated ether-linked choline-phospholipid. Med. Res. Rev. 5, $107-140$.

Spinks, N.R. \& O'Neill, C. (1987) Embryo-derived platelet activating factor is essential for the establishment of pregnancy in the mouse. Lancet 1, 106-107.

Vanderhoek, J.Y. \& Feinstein, M.B. (1979) Local anaesthetics chlorpromazine and propranolol inhibit stimulus-activation of phospholipase $A_{2}$ in human platelets. Molec. Pharmacol. 16, 171-180.
Witte, L.D., Kaplan, K., Nossel, H.L., Lages, B.A., Weiss, H.J. \& Goodman, D.S. (1978) Studies of the release from human platelets of the growth factor for cultured human arterial smooth muscle cells. Circ. Res. 42, 402-409.

Wright, K.C. \& Hedge, G.A. (1981) The effects of prostacyclin on prolactin secretion in vitro. Prostaglandins 22, 433-441.

Ylitalo, P., Kaukinen, S., Seppala, E., Nurmi, A.K., Pessi, T., Krais, T. \& Vapaatalo, H. (1984) Pharmacological effects of Iloprost (ZK36374), a stable prostacyclin analogue, in man. Biomed. Biochim. Acta. 43, S399-S402.

Ylitalo, P., Kaukinen, S., Nurmi, A.K., Seppala, E., Pessi, T. \& Vapaatalo, H. (1985) Effects of a prostacyclin analogue, Iloprost, on kidney function, reninangiotensin and kallikrein-kinin systems, prostanoids and catecholamines in man. Prostaglandins 29, 1063-1070.

Received 23 November 1987 